\title{
GENETIC ANALYSIS OF HORDEIN POLYPEPTIDES FROM SINGLE SEEDS OF BARLEY
}

\author{
P. R. SHEWRY,* HELEN M. PRATT,* R. A. FINCH† and B. J. MIFLIN* \\ * Department of Biochemistry, Rothamsted Experimental Station, Harpenden, Herts, AL5 2JQ \\ $\dagger$ Plant Breeding Institute, Maris Lane, Trumpington, Cambridge CB2 2LQ
}

Received 20.i.78

\section{SUMMARY}

A simple rapid electrophoretic method for non-destructive analysis of hordeins in barley seeds was used to show that observed gel patterns are probably determined by pairs of co-dominant alleles at two linked loci 10-16 recombination units apart.

\section{InTRODUCTION}

WE have recently developed a simple rapid procedure (Shewry, Pratt and Miflin, 1978) for the varietal identification of large numbers of single or half-seeds of barley by the analysis of hordein polypeptides.

We have used this procedure to analyse half-seeds from the $F_{1}$ generation of several crosses between barley varieties with different hordein poplyeptide patterns. In all cases the pattern observed was a hybrid between those of the parents, indicating that both parental genomes were being expressed. When seed from the $\mathrm{F}_{2}$ generation were analysed, segregation was observed. Thus this non-destructive procedure is of value in confirming crossfertilisation during barley breeding and genetics experiments.

The component polypeptides of hordein have been divided into three groups termed "A ", " B " and " C" (Køie, Ingversen, Andersen, Doll and Eggum, 1976). These groups differ in amino acid composition as well as in molecular weight and electrophoretic mobility (Miflin and Shewry, 1977). Whereas a number of different " $B$ " and " $C$ " hordein patterns occur (Shewry, Ellis, Pratt and Miflin, 1978), the low molecular weight "A" hordein (which only accounts for 1-2 per cent of the total fractions) has a constant pattern in all varieties so far investigated and may not be a true storage protein (Miflin and Shewry, 1977). A previous study by Oram, Doll and Køie (1975) suggests that the " $\mathrm{B}$ " hordein pattern is controlled by co-dominant alleles at a locus close to $\mathrm{Ml}$-a on chromosome 5 . The varieties used, however, had identical " $\mathrm{C}$ " hordein patterns and therefore the linkage relationship between these two groups could not be established.

In the Goldfoil $\times$ Nilson Ehle No. 2 cross, however, the parents have polypeptide patterns which differ in both the " $\mathrm{B}$ " and " $\mathrm{C}$ " regions (fig. 1). We therefore examined $131 \mathrm{~F}_{2}$ seeds from this cross.

\section{Methods}

The method consists of placing a crushed seed (or half-seed) in a small polypropylene test tube with $200 \mu \mathrm{l}$ of 55 per cent $(\mathrm{v} / \mathrm{v})$ propan-2-ol +2 per cent $(\mathrm{v} / \mathrm{v})$ 2-mercaptoethanol and suspending in an ultrasonic bath for 30 
minutes. After centrifugation the supernatant containing the extracted hordein is reduced to dryness at $40^{\circ} \mathrm{C}$, dissolved in $200 \mu \mathrm{l}$ buffer containing 8-M urea (Cavins and Friedman, 1968; Shewry, Ellis, Pratt and Miflin, 1978) and 1 per cent (v/v) 2-mercaptoethanol and alkylated with 4vinylpyridine $(3.0 \mu \mathrm{l})$. The alkylated solution is dialysed against a solution of 1 per cent $(\mathrm{w} / \mathrm{v})$ sodium dodecylsulphate (SDS) and electrophoresced on 17.5 per cent acrylamide gels containing 0.1 per cent SDS at $p \mathrm{H} 8.9$ (Shewry, Ellis, Pratt and Miflin, 1978).

\section{Results}

The characteristic patterns of Goldfoil and Nilsson-Ehle No. 2 in both " $\mathrm{B}$ " and " $\mathrm{C}$ " regions (figs. $1 \mathrm{i}$ and $\mathrm{lx}$ ) were discernible in the gels from individual $\mathrm{F}_{2}$ grains either separately or together giving 12 patterns in all (fig. 1). When together in a single " $\mathrm{B}$ " or " $\mathrm{C}$ " region, the two types of pattern usually differed in relative strength. The frequencies of the different patterns are given in table 1 .

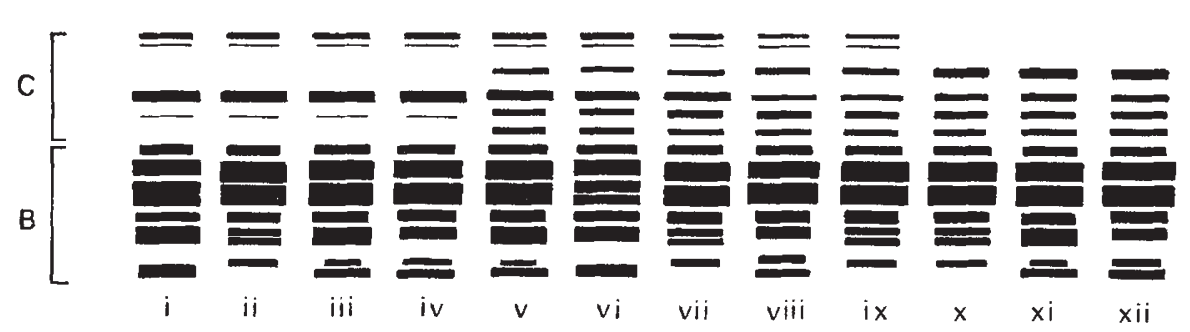

FIG. 1.-Diagrammatic representation of SDS-polyacrylamide gel separations of hordein fractions extracted from single seeds of Goldfoil, Nilsson-Ehle No. 2 and their $F_{2}$. i: single seed of Goldfoil; $\mathrm{x}$ : single seed of Nilsson-Ehle No. 2; ii-ix, xi, xii: single seeds from the $\mathrm{F}_{2}$ generation.

TABLE 1

Frequencies of " $B$ " and " $C$ " band patterns in $131 F_{2}$ grains

Pattern type and relative strength Number

\begin{tabular}{|c|c|c|c|}
\hline $\begin{array}{c}\text { Pattern } \\
\text { no. }\end{array}$ & " $\mathrm{B} "$ band region & " $\mathrm{C}$ " band region & $\begin{array}{c}\text { of } \\
\text { grains }\end{array}$ \\
\hline $\mathrm{i}$ & Goldfoil & Goldfoil & 37 \\
\hline ii & N.-E. No. 2 & Goldfoil & 1 \\
\hline iii & Strong Goldfoil + weak N.-E. No. 2 & Goldfoil & 3 \\
\hline iv & Weak Goldfoil + strong N.-E. No. 2 & Goldfoil & 3 \\
\hline $\mathbf{v}$ & Strong Goldfoil+weak N.-E. No. 2 & Strong Goldfoil + weak N.-E. No. 2 & 21 \\
\hline vi & Goldfoil & Strong Goldfoil + weak N.-E. No. 2 & 10 \\
\hline vii & N.-E. No. 2 & Strong Goldfoil + weak N.-E. No. 2 & 1 \\
\hline viii & Weak Goldfoil+strong N.-E. No. 2 & Weak Goldfoil+strong N.-E. No. 2 & 17 \\
\hline $\mathrm{ix}$ & N.-E. No. 2 & Weak Goldfoil + strong N.-E. No. 2 & 2 \\
\hline $\mathbf{x}$ & N.-E. No. 2 & N.-E. No. 2 & 34 \\
\hline $\mathrm{xi}$ & Strong Goldfoil + weak N.-E. No. 2 & N.-E. No. 2 & 1 \\
\hline xii & Weak Goldfoil + strong N.-E. No. 2 & N.-E. No. 2 & 1 \\
\hline
\end{tabular}


In ii-iv, vi, vii, ix, xi and xii, the patterns differ in the " $\mathrm{B}$ " and " $\mathrm{C}$ " regions and so each region must be controlled by a separate locus. Let us assume that Goldfoil and Nilsson-Ehle No. 2 carry different alleles at one locus determining the " $\mathrm{B}$ " pattern and at another determining the " $\mathrm{C}$ " pattern (symbolised as $B g, B n, C g$ and $C n$, respectively) and that the alleles act independently with a dose effect. Then a strong pattern from one parent coexisting with a weak one from the other in a given band region implies that two alleles determining the relevant pattern from the first parent and one allele from the second were present in the endosperm genotype. Thus the observed patterns iii and v imply the genotypes, $B g$ $B g B n, C g C g C g$ and $B g B g B n, C g C g C n$, respectively. From this it can be deduced that the gametic genotypes must have been $B g C g$ in both eggs and $B n C g$ and $B n C n$ in the respective sperm nuclei.

The frequencies of the four gametic genotypes from the $F_{1}$ are different (table 2); the two parental types have about equal frequencies but are greatly in excess of the two recombinant types. This clearly implies that the two loci, $B g / B n$ and $C g / C n$, are linked. The male and female recombination frequencies (12.98 \pm 2.94 per cent and $4.58 \pm 1.83$ per cent, respectively)

TABLE 2

Gametic genotype frequencies implied by data in table 1

$\begin{array}{lcccc} & B g C g & B n C g & B g C n & B n C n \\ \text { Male } & 57 & 6 & 11 & 57 \\ \text { Female } & 71 & 5 & 1 & 54 \\ \text { Total } & 128 & 11 & 12 & 111\end{array}$

are different $(\mathrm{P}<0.02)$ and there are slightly more Goldfoil than NilssonEhle No. 2 type gametes on the female side. There was no seed sterility to suggest differential viability on the female side and so the above departures from the hypothetical expectations may be due to misclassification of some band patterns. Hence, the best interpretation of the results is probably that the " $\mathrm{B}$ " and " $\mathrm{C}$ " patterns are determined by two loci showing approximately $10-16$ per cent recombination.

Using the one-dimensional SDS electrophoresis it was not possible to detect recombination in this cross within the " $B$ " and " $C$ " hordein groups. Consequently it is probably not worth while, on these results, suggesting alternative hypotheses invoking more loci. Such possibilities are currently being investigated using two-dimensional separation procedures and crosses between different varieties.

\section{REFERENCES}

CAVINS, J. F., AND FRIEDMAN, M. 1968. Specific modification of protein sulphydryl groups with $\alpha, \beta$-unsaturated compounds. 7 . biol. Chem., 244, 3357-3360.

KøIE, B., INGVERSEN, J., ANDERSEN, A. J., DOLL, H., AND EGGUM, B. o. 1976. In: Evaluation of Seed Protein Alterations by Mutations Breeding. Research Co-ordination Meeting, Hahnenklee, 1975, IAEA, Vienna, p. 55.

MIFLIN, B. J., AND SHEWRY, P. R. 1977. In Techniques for the Separation of Barley and Maize Proteins. Publ. by the Commission of the European Communities, Luxembourg.

ORAM, R. N., DOLL, H., AND KøIE, B. 1975. Genetics of two storage protein variants in barley. Hereditas, 80, 53-58. 
SHEWRY, P. R., ELLIS, J. R. S., PRATT, H. M., AND MIFLIN, B. J. 1978. A comparison of methods for the extraction and separation of hordein fractions from 29 barley varieties. 7 . Sci. Fd Agric. (in press).

SHEWRY, P. R., PRATT, H. M., AND MIFLIN, B. J. 1978. Varietal identification of single seeds of barley by analysis of hordein polypeptides. 7. Sci. Fd Agric. (in press). 